\title{
KEPEMIMPINAN PEREMPUAN PADA MADRASAH ALIYAH DI KABUPATEN BONE
}

\author{
Abstrak \\ St. Zakiah \\ Sittizakiah15@gmail.com
}

\begin{abstract}
Abstrak: Penelitian ini mengkaji tentang kepemimpinan perempuan pada Madrasah Aliyah di Kabupaten Bone. Tujuan penelitian ini adalah untuk mengetahui profil kepemimpinan kepala Madrasah Aliyah perempuan di Kabupaten Bone, pandangan tokoh agama dan tokoh masyarakat Bone terhadap kepemimpinan perempuan pada Madrasah Aliyah di Kabupaten Bone dan kontribusi kepemimpinan perempuan sebagai kepala Madrasah Aliyah di Kabupaten Bone. Penelitian ini adalah penelitian kualitatif dengan menggunakan pendekatan fenomenologi dan filosofis. Sumber data dalam penelitian ini adalah data primer dan data sekunder. Pemilihan sumber data dilakukan dengan teknik purposive sampling. Metode pengumpulan data dilakukan melalui observasi, wawancara mendalam dan dokumentasi. Teknik pengolahan data dilakukan dengan cara reduksi data, display data dan penarikan kesimpulan. Selanjutnya pengujian keabsahan data dilakukan dengan cara trigulasi dan menggunakan bahan referensi. Hasil penelitian kepemimpinan perempuan pada Madrasah Aliyah di Kabupaten Bone, ditemukan bahwa gaya kepemimpinan kepala Madrasah Aliyah perempuan di Kabupaten Bone, cenderung demokratis. Hambatan yang dihadapi kepala Madrasah Aliyah perempuan di Kabupaten Bone, ada dua yaitu hambatan internal dan hambatan eksternal. Hambatan internal berasal dari dalam madrasah itu sendiri. Dengan bermodalkan ketekunan dan keuletan hambatan internal dapat diatasi oleh kepala Madrasah Aliyah perempuan di Kabupaten Bone. Sedangkan hambatan eksternal yang berasal luar madrasah, yaitu hambatan yang berasal dari lingkungan keluarga kepala madrasah itu sendiri. Namun hambatan tersebut mampu diatasi oleh kepala Madrasah Aliyah perempuan yang ada di Kabupaten Bone. Kepemimpinan kepala Madrasah Aliyah perempuan di Kabupaten Bone mendapat dukungan dari tokoh agama dan tokoh masyarakat Kabupaten Bone. Kepala Madrasah Aliyah perempuan di Kabupaten Bone memberikan kontribusi dalam bidang pendidikan, keagamaan dan sosial kemasyarakatan.
\end{abstract}

KATA KUNCI: Kepemimpinan Perempuan

\section{A. Latar Belakang}

Kepemimpinan adalah suatu sikap mempengaruhi orang lain untuk mencapai suatu tujuan dengan visi dan misi yang kuat. Jika berbicara tentang kepemimpinan, di dalam benak masyarakat umumnya identik dengan kaum adam, namun jika ditelaah, perempuan juga memiliki jiwa kepemimpinan yang tidak jauh berbeda keahliannya dalam memberi arahan, berorasi maupun beretorika atau bahkan memberi gagasan. (Wahjosumidjo, Jakarta, 2013: 16). 
Pada dasarnya semua orang dapat menjadi pemimpin termasuk perempuan. Perempuan ibarat sebuah bangunan yang kokoh dan merupakan pondasi yang berstruktur kuat. Hal ini dapat dilihat dari perannya dalam kehidupan bermasyarakat. Perempuan bukan hanya sebagai objek pembangunan tetapi juga menjadi subjek pembangunan.( Julismin Harahap, Jurnal, 2014: 40-45. Suatu hal yang memprihatinkan apabila dilihat dari sudut pandang yang berlainan, banyak kenyataan peran seorang perempuan tradisional dianggap sebagai pelengkap dalam kehidupan laki-laki. Contohnya perempuan di bawah umur sudah diharuskan menikah tanpa mengenyam pendidikan yang memadai.

R.A. Kartini, merupakan salah satu sosok perempuan Indonesia yang mengawali peran perempuan di dunia publik, perjuangan yang dilakukan khususnya dalam pergerakan emansipasi perempuan dampaknya terlihat sampai sekarang. Keberadaan perempuan kini mulai dihargai dan disetarakan walaupun masih banyak pro dan kontra. (Kementerian Pemberdayaan Perempuan dan Perlindungan Anak dan Badan Pusat Statistik. "Pembangunan Manusia Berbasis Gender 2013). Oleh karena itu, Megawati Soekarno Putri merupakan bukti nyata bahwa perempuan dapat menjadi seorang pemimpin, bahkan dapat menjadi kepala negara.

Peranan perempuan dalam kepemimpinan bukanlah suatu hal yang aneh. Istilah dalam kesetaraan gender disebut dengan kesetaraan peran lakilaki dan perempuan dalam mendapatkan hak-haknya sebagai makhluk sosial. Hal ini diharapkan mampu berperan dan berpatisipasi dalam semua kegiatan seperti politik, ekonomi, sosial, budaya, pendidikan serta kesamaan dalam menikmati pembangunan. (Delima Hasri Azahari, 2016: 1-10.)

Keberadaan perempuan sebagai pemimpin membawa dampak yang positif. Kondisi ini menjadikan permasalahan kesetaraan gender sedikit teratasi, ditandai dengan tidak adanya perbedaan antara perempuan dan 
laki-laki. Oleh karena itu, perempuan dan laki-laki memiliki peluang atau akses yang sama dalam kepemimpinan. Sehingga saat ini perempuan dapat membuktikan mampu memberikan kontribusi pembangunan negara yang lebih baik. (Murniati Ruslan, 2010: 79-96.)

Manfaat persamaan serta keadilan dalam pembangunan mesti dibuktikan bahwa perempuan semakin maju dalam kemimpinan. Kehadiran seorang perempuan dalam kepemimpinan, terutama dalam pembangunan sekarang ini sangat dibutuhkan dari segi pemikiran dan kreasi untuk mengembangkan dan mewujudkan tujuan pembangunan. Islam juga tidak menoleransi adanya perbedaan atau diskriminasi di antara sesama manusia.( Pinky Saptandari, 1999: 12).

Demikian firman Allah dalam QS Al-Ah\}za>b/33: 35

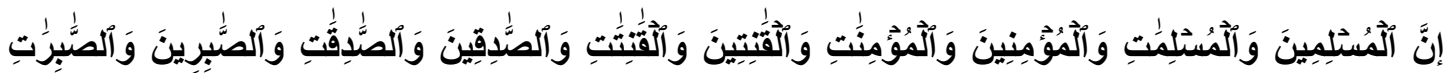

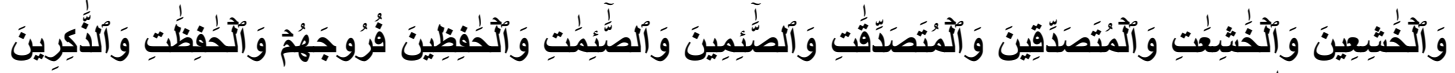

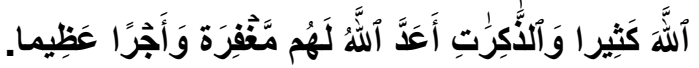

Terjemahnya:

Sesungguhnya laki-laki dan perempuan yang muslim, laki-laki dan perempuan yang mukmin, laki-laki dan perempuan yang tetap dalam ketaatannya, laki-laki dan perempuan yang benar, laki-laki dan perempuan yang sabar, laki-laki dan perempuan yang khusyu, laki-laki dan perempuan yang bersedekah, laki-laki dan perempuan yang berpuasa, laki-laki dan perempuan yang memelihara kehormatannya, laki-laki dan perempuan yang banyak menyebut (nama) Allah, Allah telah menyediakan untuk mereka ampunan dan pahala yang besar.

Sebenarnya pandangan Alquran terhadap keberadaan perempuan tidak bersifat diskriminatif, meskipun tetap mengakui adanya perbedaan antara laki-laki dan perempuan. Memperbaiki nasib kaum perempuan justru merupakan salah satu misi di antara sekian banyak misi yang diemban oleh 
Alquran. Gagasan emansipasi yang tersirat di dalam ayat-ayat Alquran mencakup pemulihan status mereka sebagai manusia yang sama kualitasnya dengan laki-laki, memberikan hak memiliki dan hak-hak lainnya seperti yang dimiliki oleh kaum laki-laki secara adil dan proporsional. Demikian dijelaskan dalam QS Al-Taubah/9:71

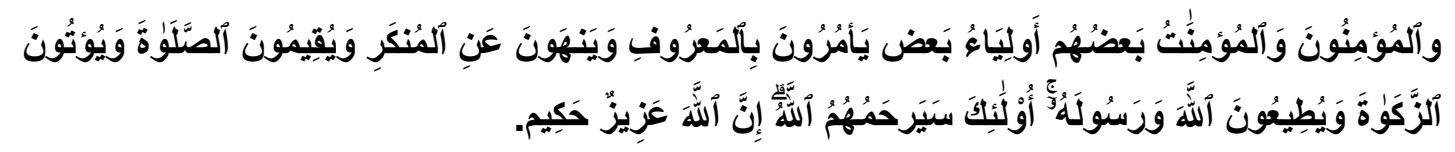

Terjemahnya:

Dan orang-orang yang beriman, lelaki dan perempuan, sebahagian mereka (adalah) menjadi penolong bagi sebahagian yang lain. Mereka menyuruh (mengerjakan) yang ma'ruf, mencegah dari yang munkar, mendirikan shalat, menunaikan zakat dan mereka taat pada Allah dan Rasul-Nya. Mereka itu akan diberi rahmat oleh Allah; sesungguhnya Allah Maha Perkasa lagi Maha Bijaksana.

Dalam pandangan Qasim Amin (1863-1908 M) perempuan sama dengan laki-laki tidak ada perbedaan. Hakikat kemanusiaan antara keduanya, dari fungsi anggota tubuh, perasaan dan daya pikir, kecuali pada perbedaan jenis kelamin dan hal-hal yang berkenaan dengannya. Selama ini perempuan tidak memiliki banyak kesempatan untuk melatih pikiran sebagaimana kaum laki-laki, maka ada kalanya laki-laki tampak lebih ungggul. Kelihatanya Qasim Amin sangat mengharapkan meningkat dan majunya pendidikan perempuan.

Kasus pendidikan perempuan di Bone cukup maju, sehingga ada beberapa perempuan yang menjadi kepala madrasah. Pendidikan di Kabupaten Bone terbilang maju dan berkembang, hal ini terlihat dari prestasi Kabupaten Bone dalam beberapa tahun terkahir meraih urutan nilai kelulusan yang terbilang tinggi. Jumlah masyarakat dapat terwakili dari jumlah sekolah dan madrasahnya. Sebagai kajian dalam disertasi ini jumlah madrasah di 
Kabupaten Bone yang mendekati angka tiga ratusan madrasah terhitung mulai, RA (Raudhatul Athfal) MI (Madrasah Ibtidaiyah) MTS (Madrasah Tsanawiyah) MA (Madrasah Aliyah) dan beberapa perguruan tinggi swasta dan satu Negeri (IAIN Bone). Walaupun masyarakat Bone dikenal feodal dan sangat kuat memegang adat dan budayanya, namun tidak mesti mereka tidak peduli dengan nilai-nilai kesetaraan antara laki-laki dan perempuan, mengingat budaya masyarakat Bone sangat menghargai wujud dan keberadaan manusia apalagi kedudukan dan posisi perempuan di tengah masyarakat. Namun tidak dipungkiri masih ada saja terjadi persoalanpersoalan gender yang kerap menyudutkan dan melemahkan kaum perempuan dalam peran dan aktifitasnya di tengah masyarakat. Dalam penelitian ada lima perempuan sebagai kepala Madrasah Aliyah di kabupaten Bone yang dijadikan sampel, untuk diwawancarai lebih lanjut.

\section{B. Pembahasan}

\section{Profil Kepemimpinan Perempuan Sebagai Kepala Madrasah Aliyah di Kabupaten Bone}

Madrasah Aliyah di Kabupaten Bone, menurut data yang diperoleh dari seksi Penmad Kantor Kementerian Agama Kabupaten Bone, berjumlah 41 Madrasah Aliyah, yang tersebar di 27 Kecamatan yang ada di Kabupaten Bone. Ada 15 orang perempuan sebagai kepala Madrasah Aliyah di Kabupaten Bone dan 26 orang kepala Madrasah Aliyah laki-laki. Dari 41 Madrasah Aliyah di kabupaten Bone, peneliti menjadikan 5 Madrasah Aliyah sebagai purposive sampling. Berikut profil kepememimpinan perempuan sebagai kepala Madrasah Aliyah di Kabupaten Bone yang pembahasannya berfokus pada gaya kepemimpinan dan hambatan kepemimpinan kepala Madrasah Aliyah perempuan di Kabupaten Bone. 


\section{a. Kepemimpinan Kepala Madrasah Aliyah Perempuan di Kabupaten Bone}

1). Madrasah Aliyah al-Juna>idiyah\} Biru

Kepemimpinan Ibu Murniati sebagai kepala MA al-Juna>idiyah Biru Kabupaten Bone dapat dikatakan berhasil dan sukses. Gaya kepemimpinannya disenangi oleh para guru-guru dan staf di MA alJuna>idiyah Biru sebagai mitra kerjanya di madrasah. Informasi hal ini diperoleh dari hasil wawancara dengan bapak Drs. Abd. Syukur, salah satu guru MA al-Juna>idiyah Biru, diperoleh jawaban beberapa data tentang kepemimpinan kepala madrasah sebagai berikut:

Saya sangat senang menjadi guru di sini, karena sifat kekeluargaannya sangat tinggi, kami sesama guru saling menasehati jika ada masalah. Kapala madrasah yang lalu adalah seorang laki-laki, namun kurang menunjukkan keteladanan dalam hal kedisiplinan kerja, sering keluar untuk keperluan pribadi dibanding urusan dinas. Menurut saya kepala madrasah laki-laki atau perempuan sama saja, asal sesuai aturan yang berlaku, bersifat tegas dan tidak diskriminatif. Kepala madrasah kami sekarang adalah seorang perempuan, saya senang karena beliau tegas, disiplin, tidak pandang bulu dalam memimpin, beliau tidak membeda-bedakan guru-guru walaupun kami memiliki latar belakang pendidikan yang berbeda. (wawancara: Abd. Syukur)

Hal senada juga disampaikan oleh Ibu Astika Amrah, S.Pd., guru bahasa Inggris MA al-Juna>idiyah\} Biru, berikut petikan wawancaranya:

Selama mengajar di sini banyak hal yang saya dapatkan selain ilmu pendidikan, seperti kegiatan keagamaan dan sosial. Menurut saya dari segi manajemen kepala madrasah perempuan mempunyai nilai lebih dibanding laki-laki. Selama Ibu Murniati, S.Ag, M.Pd.I., menjadi kepala madrasah di sini banyak prestasi yang di raih oleh siswa baik di tingkat 
Kecamatan, Kabupaten bahkan tingkat Nasional. Tahun kemarin 2017, siswa kami meraih juara 1 cipta baca puisi tingkat Nasional. Selain itu di tahun yang sama siswa kami juga meraih juara 1 PPSN (pramuka) tingkat Nasional. Madrasah kami juga baru-baru ini di akreditasi dan hasilnya $A$. selama ini hanya akreditasi $C$, nanti setelah ibu Murni jadi kepala madrasah, Alhamdulillah kita bisa memperoleh nilai akreditasi $A$.

Bustamin, S.Sos, M.Si., kepala tata usaha MA al-Juna>idiyah\} Biru mengiyakan hal tersebut di atas, dalam sesi wawancara mengatakan:

Kepemimpinan Ibu Murniati, S.Ag, M.Pd.I., di MA al-Juna>idiyah\} Biru, saya acungi jempol, beliau tegas, disiplin, lincah sehingga madrasah ini berkembang selama dipimpin oleh beliau. Piala sudah ada 3 lemari sebagai bukti keberhasilan beliau memimpin, malahan sebahagian piala diserahkan kepada siswa karena tidak muat tempatnya he he he he. Pemimpin perempuan atau laki-laki bagi saya tidak ada masalah yang penting mau berbuat untuk madrasah. Jangan hanya cerita panjang lebar tapi bukti tidak ada he he he. Walaupun begitu namanya manusia biasa pasti punya kekurangan karena tidak ada manusia yang sempurna. Hanya Allah yang Maha sempurna.

Pengakuan para guru MA al-Juna>idiyah\} Biru di atas, menandakan kesuksesan kepala MA al-Juna>idiyah\} Biru dalam memimpin madrasah. Prestasi yang diraih oleh MA al-Juna>idiyah\} Biru, bukan hanya di bidang akademik dan non akademik, tetapi juga kesuksesan dalam mengembangkan madrasah dari akreditasi C menjadi akreditasi A. Ini membuktikan bahwa kepala Madrasah Aliyah perempuan di Kabupaten Bone, mempunyai andil yang besar dalam mengembangkan pendidikan di Kabupaten Bone.

Memimpin tidak hanya membutuhkan kemauan, namun juga kemampuan. Kemampuan adalah kecakapan leadership seseorang dalam 
mengelola tugas-tugas yang diembannya. Oleh karena itu, gaya kepemimpinan sangat penting untuk dimiliki seseorang agar sukses dalam kepemimpinannya. Seperti halnya Ibu Murniati, mustahil dapat memperoleh kemajuan nilai akreditasi jika gaya kepemimpinanya tidak disukai oleh bawahanya di MA al-Juna>idiyah Biru. Karena hasil dari sebuah usaha yang dilakukan oleh pemimpin merupakan cerminan kualitas suatu lembaga pendidikan.

Dari beberapa data wawancara di atas dapat diketahui bahwa gaya kepemimpinan kepala MA al-Juna>idiyah\} Biru adalah gaya kepimpinan transformasional. Tampaknya gaya kepemimpinan Ibu Murniati sebagai kepala MA al-Junasidiyah\} Biru, tidak hanya mengandalkan telunjuk atau perintah saja kepada bawahanya, namun beliau menganggap bawahanya sebagai mitra dalam bekerja. Karena Ibu Murniati sangat paham, bahwa kesuksesan suatu usaha adalah kesuksesan bersama, begitu pula sebaliknya.

Gaya kepemimpinan transformasional memang cocok di terapkan di setiap madrasah, begitu pula di MA al-Juna>idiyah\} Biru, mengingat kultur masyarakatnya yang masih kental memegang budaya dan adat istiadatnya. Ditambah lagi MA al-Juna>idiyah\} Biru merupakan salah satu Madrasah Aliyah swasta yang bernaung di bawah pondok pesantren al-Juna>idiyah\} Biru yang didirikan oleh Gurutta K.H. Muhammad Djunaid. Pesantren yang cukup terkenal di masyarakat baik lokal maupun nasional, dikenal oleh masyarakat sebagai penghasil ulama-ulama tahfiz Qurán, seperti K.H. Khuzaifah, K.H. Hasan Basri, K.H. Syam Amir dan lain sebagainya.

Dengan gaya kepemimpinan transformasional yang dimilikinya lbu Murniati merupakan salah satu kepala Madrasah Aliyah swasta perempuan di Kabupaten Bone, yang sukses mengembangkan madrasahnya. Kesuksesan yang diraih semata-mata karena kerja keras di dalam mengembangkan ideidenya demi kemajuan madrasah yang dipimpinnya. Kemajuan madrasah 
yang ada di Kabupaten Bone tidak ditentukan oleh jenis kelamin, tetapi di tentukan oleh kompetensi dan gaya kepemimpinan kepala madrasah yang memimpinnya.

2). Madrasah Aliyah Negeri 4 Bone

Madrasah Aliyah Negeri 4 Bone yang selanjutnya disebut (MAN 4 Bone) saat ini dipimpin oleh Ibu Dra. Hj. Adila sebagai kepala madrasahnya, sebelumnya madrasah ini merupakan kelas jauh dari MAN 3 Bone. Pada tahun 2010 MAN 4 Bone berdiri sendiri dan yang dipilih menjadi kepala madrasahnya adalah seorang perempuan yang bernama Dra. Hj. Adila, sebelumnya dipimpin oleh laki-laki yaitu Bapak Drs. H. Abd Latif M.Pd.

Ibu Adila seorang pemimpin yang cukup terkenal di sekitar masyarakat Kajuara. Beliau dikenal selain sebagai kepala MAN 4 Bone, beliau juga sebagai ketua Tim penggerak PKK di Kecamatan kajuara. Beliau merupakan warga asli desa Waetuo Kecamatan Kajuara dan salah satu tokoh masyarakat di Desanya.

Sebagai kepala MAN 4 Bone, kepemimpinan lbu Adila cukup berhasil, sebagaimana hasil wawancara bersama salah seorang guru MAN 4 Bone, yaitu Ibu Suhaeni, S.Pd., mengatakan:

Dulunya MAN 4 Bone ketika masih berstatus kelas jauh, dari MAN 3 Bone yang kepala madrasahnya laki-laki, madrasah ini kurang begitu berkembang. Jumlah siswanya sangat sedikit hanya sekitar 60 orang. Kemudian jumlah gurunya juga masih mengharap dari MAN 3 Bone sebagai induknya. Kondisinya susah berkembang karena kepemimpinan yang kurang maksimal, namun setelah madrasah ini ditingkatkan statusnya menjadi mandiri dengan kepemimpinan sendiri, alhmadulillah sejak tahun 2010 resmi menjadi MAN 4 Bone dan yang diangkat menjadi kepala madrasah adalah seorang perempuan yaitu ibu Dra. Hj. Adila. Sekarang jumlah siswa mencapai 310 orang, guru 32 
orang yang terdiri dari 23 perempuan 9 laki-laki dan staf administrasi 7 orang, 5 orang perempuan 2 orang laki-laki. Sejak itulah mulai ada perkembangan jumlah siswa dan bangunan serta jumlah guru dan staf administrasi di MAN 4 Bone. Peningkatan jumlah siswa juga didukung oleh peningkatan kualitas pendidikan yang diberikan kepada masyarakat. Sejak ibu Adila jadi kepala madrasah, banyak prestasi yang diraih oleh siswa baik prestasi akademik maupaun prestasi non akademik. Nilai akreditasi madrasah juga meningkat dari akreditasi $B$ menjadi akreditasi $A$.

Kesuksesan sebuah kepemimpinan tentunya tidak terlepas dari dukungan banyak hal, termasuk dukungan dari stakeholder yang ada. Dukungan dari pihak-pihak terkait sangat penting untuk kemajuan madrasah, seperti dukungan para guru-guru dan staf MAN 4 Bone, para siswa dan masyarakat. Namun dukungan-dukungan tersebut juga tidak akan berarti jika dari segi karakter personal kepala madrasah yang kurang baik atau tidak disenangi oleh bawahanya.

Kesuksesan kepemimpinan Ibu Adila tidak hanya ditentukan dari dukungan-dukungan seperti yang disebutkan di atas, namun yang lebih penting adalah karakter dan gaya kepemimpinan yang digunakan atau diterapkan kepada bawahannya dalam memimpin di MAN 4 Bone. Dapat dikatakan kepemimpinan Ibu Adila sangat demokratis kepada bawahannya. Pendekatan kekeluargaan dan kepemimpinan yang demokratis terbukti menghasilkan kesuksesan dalam kepemimpinan beliau di MAN 4 Bone. Inilah ciri khas kepemimpinan Ibu Adila sebagai salah satu kepala Madrasah Aliyah perempuan di Kabupaten Bone.

3). Madrasah Aliyah Mattiro Deceng

Madrasah Aliyah Mattiro Deceng, selanjutnya disebut (MA Mattiro Deceng). Terletak di desa Matiro Deceng, Kecamatan Libureng Kabupaten Bone, kurang lebih $70 \mathrm{~km}$ dari Kota Watampone atau 2 jam perjalanan 
menggunakan kendaraan mobil. Untuk ke lokasi MA Matiro Deceng, penulis membutuhkan sekitar 1 jam berkendaraan karena lokasi MA Mattiro Deceng kurang lebih sejauh $20 \mathrm{~km}$ dari Dusun seppange Desa Tungke Kecamatan Bengo, yang menjadi tempat domisili penulis. Kondisi lokasi MA Matiro Deceng, sangat bersahaja, karena terletak agak jauh dari perkampungan penduduk Desa, ketika menyusuri lokasi madrasah, melalui jalanan yang belum diaspal melewati beberapa kebun warga, namun ketika tiba di lokasi, terlihat kondisi madrasah yang sangat bersih, tertata rapi dan dihiasi tanaman-tanaman bunga, sehingga elok dipandang mata. Walaupun beberapa bangunannya masih darurat, hanya terbuat dari dinding kayu dan seng, namun cukup terawat. Jumlah siswa 60 orang dan guru 15 orang.

Kepemimpinan kepala MA Mattiro Deceng yang bersungguh-sungguh dalam meningkatkan keberhasilan proses pembelajaran, tentunya menjadi perhatian semua pihak, termasuk para guru-guru di MA Mattiro Deceng. Hal ini seperti yang diungkapkan dalam sesi wawancara kepada Bapak Muhammad Yusuf, SE., selain sebagai guru beliau juga mendapat tugas tambahan sebagai Wakamad bidang kurikulum, adapun inti wawancara adalah sebagai berikut:

Pada intinya apa yang dikemukakan oleh kepala madrasah MA Matiro deceng sama dengan guru-guru, sama-sama menginginkan keberhasilan dalam pembelajaran, terlaksananya program madrasah dengan baik, meningkatnya prestasi siswa baik dalam pembelajaran, maupun dalam prestasi ekstra kurikuler di MA Matiro Deceng. Bagi kami perempuan sebagai kepala madrasah tidak menjadi masalah, justru kami merasakan ada perbedaan ketika madrasah dikepalai laki-laki, ada keengganan dan keseganan untuk memberikan atau mengusulkan ide, namun sekarang dengan perempuan sebagai kepala madrasah kami, justru kami merasa lebih kekeluargaan, terbuka dan kami tidak 
sungkan-sungkan mengemukakan ide-ide kami, karena kepala madrasah kami sangat perhatian dan menghargai pendapat setiap dari gurunya. Dan Alhamdulillah madrasah kami sekarang terakreditasi B. Ini berkat kerja keras kepala madrasah kami.

Tampilnya perempuan sebagai kepala madrasah, memberikan gambaran bahwa peran sosial dan masyarakat, bukan hanya menjadi tanggung jawab kaum laki-laki saja, hal ini menjadi tanggung jawab antara laki-laki dan perempuan. Sebagaimana hasil wawancara yang ungkapkan Bapak Abdul Azis, S.Pd., salah satu guru MA Mattiro Deceng sebagai berikut:

Sebagai guru laki-laki di MA Mattiro Deceng, saya tidak bisa memberikan perbandingan antara kepemimpinan perempuan dan kepemimpinan laki-laki. Bagi saya siapapun dia, apakah dia laki-laki atau perempuan, yang penting dia bisa memimpin dengan baik, mampu memajukan sekolah, bisa bekerja sama dengan guru- guru dan staf. Kepala madrasah kami yaitu lbu Nurlaela saya anggap seorang pemimpin yang baik dan bertanggung jawab. Kami guru-guru sangat senang dengan kepemimpinan beliau.

Hasil wawancara dengan Ibu Nirwana, S.Ag., Guru Fikih MA Mattiro Deceng, mengatakan bahwa:

Iklim kerja itu berhubungan dengan lingkungan kerja yang harus diciptakan untuk mendukung aktivitas pelaksanaan pekerjaan dan penyelenggaraan pembelajaran yang berlangsung di madrasah. Saya selalu melakukan penataan ruang kelas bersama siswa dan juga ruang kerja guru bersama rekan guru lainnya. Saya menginginkan iklim kerja yang kondusif untuk melaksanakan pembelajaran di kelas sehingga kebersihan kelas dan kerapian siswa menjadi prioritas utama bagi saya di madrasah. Hal ini juga sering disampaikan oleh kepala madrasah 
agar senantiasa menjaga kebersihan dan keindahan lingkungan madrasah.

Perhatian dari semua guru sebenarnya tergantung dari sikap dan gaya kepemimpinan kepala madrasah. Guru-guru beserta staf akan sungguhsungguh bekerja, jika kepala madrasah juga memperlihatkan semangat dan kesungguhanya dalam menciptakan kebersamaan dalam bekerja. Salah satu data hasil wawancara bersama seorang guru MA Mattiro Deceng, Bapak Asri, S.Pd., Guru Bhs. Inggris MA Mattiro Deceng, mengatakan bahwa:

Saya sering kali melihat kepala madrasah sangat peduli dengan kondisi madrasah dan ruangan kantor dan kelas belajar. Kepala madrasah sering kali saya dapati sedang menata tempat kerja dan ruang guru untuk mencari kesesuain agar dapat bekerja dengan baik. Di sini kepala madrasah selalu berusaha menciptakan iklim yang baik dan kondusif dalam bekerja. Seperti pekerjaan saya hanya mengajar tetapi ada juga pekerjaan lain yang diberikan kepala madrasah sehingga saya membutuhkan iklim kerja yang baik agar saya dapat bekerja dengan baik terutama pencahayaan, fentilasi udara yang bersih dan udara di dalam ruangan. Semua ini perlu di jaga dan ditata agar kita semua tetap sehat di ruang kerja maupun di ruang kelas.

Berdasakan hasil wawancara yang dikemukakan sebelumnya, maka dapat diketahui bahwa iklim kerja di madrasah yang terbentuk dan penataan ruang belajar dan ruang kerja untuk mendukung penyelenggaraan pembelajaran yang juga menjadi tanggung jawab kepala madrasah dengan perannya untuk mewujudkan iklim kerja yang aman nyaman dan tenteram.

4). Madrasah Aliyah al-Rahma>n Kaju

Madrasah Aliyah al-Rahma>n Kaju Kecamatan Sibulue yang selanjutnya dalam pembahasan ini disebut (MA al-Rahma>n Kaju), 
merupakan Madrasah Aliyah yang dipimpin oleh seorang perempuan. Ibu $\mathrm{Hj}$. Rahmatan, S.Ag, M.Pd.I., sebagai kepala madrasahnya sekaligus sebagai tokoh pendiri MA al-Rahma>n Kaju. MA al-Rahma>n Kaju, terletak di Desa Kaju, Kecamatan Sibulue Bone bagian selatan, sekitar $85 \mathrm{~km}$ perjalanan ditempuh dari kota Watampone. Walaupun letaknya lumayan jauh dari ibu kota Watampone, namun MA al-Rahma>n Kaju ini sangat aktif mengikuti kegiatan-kegiatan yang dilaksanakan Kemenag maupun Diknas Kabupaten Bone.

Ketika penulis mengunjungi MA al-Rahma>n Kaju untuk melakukan observasi dan wawancara pada hari Kamis tanggal 22 Februari 2018, kesan pertama yang penulis dapatkan adalah MA al-Rahma>n Kaju adalah madrasah yang nyaman, indah, bersih dan tertata rapi. Penulis merasa nyaman berada di lokasi karena dikelilingi oleh bunga warna warni yang tertata rapi di halaman madrasah. MA al-Rahma>n Kaju memiliki tiga ruang kelas permanen cukup menampung jumlah siswa sekitar 51 orang dan guru 12 orang.

Kepemimpinan Ibu Hj. Rahmatan di MA al-Rahma>n Kaju terbilang cukup berhasil, dalam bidang peningkatan akreditasi dan prestasi madrasah. MA al-Rahma>n Kaju saat ini cukup diminati oleh masyarakat, dengan bertambahnya jumlah siswa tiap tahunnya yang datang mendaftar dan bersekolah di Madrasah Aliyah tersebut. Ini menunjukan meningkatnya animo masyarakat untuk menyekolahkan anak-anak mereka di MA al-Rahma>n Kaju, dibanding dengan tahun-tahun sebelumnya, yang rata hanya menerima sekitar 10-15 orang siswa setiap tahunnya, jika dibanding dengan sekarang dalam kurun tiga tahun berturut-turut jumlah siswa yang diterima di atas 30 orang per tahunya.

Wawancara tentang kepemimpinan Ibu Hj. Rahmatan sebagai kepala madrasah dapat dilihat dari wawancara dari beberapa orang guru yang ada MA al-Rahma>n Kaju, yaitu Ibu Muafiah, S.Ag., sebagai wakil kepala 
madrasah (wakamad) MA Al-Rahma>n Kaju, dipeoleh data hasil wawancara sebagai berikut:

Alhamdulillah semenjak menjadi guru di MA Al-Rahma>n Kaju ini, banyak sekali pengalaman yang saya dapatkan, utamanya dalam hal pengajaran dan pembelajaran. Perasaan saya cukup senang menjadi guru disini dan bersama-sama dengan ibu kepala madrasah yang sangat baik dalam memimpin kami." Pendapat saya tentang kepemimpinan kepala madrasah disini, sangat baik, tegas dan disiplin, semua guru selalu dimotivasi agar melaksanakan tugas dengan baik, sehingga siswa-siswi yang ada di MA Al-Rahma>n Kaju ini, dapat bersaing dengan siswa-siswi yang ada di madrasah atau sekolah lain yang sederajat. Kepala madrasah kami sangat lincah dalam mengurus madrasah kami, bahkan kami pernah dapat bantuan dari Australia berkat kelincahan kepala madrasah kami.

Kepala madrasah adalah seorang pemimpin dalam bidang pendidikan, sehingga kahadirannya sangat diperlukan dalam sebuah lembaga madrasah tersebut. Karena kepemimpinan dalam pendidikan bertujuan untuk mencapai tujuan yang telah dicita-citakan. Pada intinya jika sebuah kegiatan atau usaha yang dilakukan melibatkan banyak orang dan berlangsung lama, serta memiliki perencanaan visi dan misi, maka pastilah membutuhkan seorang pemimpin di antara mereka agar kegiatan tersebut memiliki tanggung jawab dan peran masing-masing bagi yang memimpin dan yang dipimpin.

Berdasarkan kedua hasil wawancara tersebut, maka dapat dikemukakan bahwa tugas kepala madrasah sebagai penagggung jawab dalam penyelenggaraan pendidikan menyangkut keseluruhan aspek kegiatan madrasah yang dipimpinnya. Menumbuh kembangkan jiwa kompetitif untuk meraih prestasi pada semua warga madrasah, sehingga mampu menghadapi persaingan dan perubahan yang sering terjadi. Kepala 
madrasah bertanggung jawab terhadap eksistensi madrasah dalam menghadapi persaingan yang terus terjadi sepanjang kalender pendidikan.

Perkembangan yang terjadi di madrasah saat ini adalah penyediaan fasilitas dan media pembelajaran yang merupakan bagian dari kebutuhan pembelajaran untuk mewujudkan prestasi yang unggul. Tugas kepala madrasah untuk mewujudkan madrasah unggulan adalah menyiapkan kebutuhan pembelajaran dengan memanfaatkan dana madrasah secara efektif dan efisien. Selain itu kepala madrasah juga harus mengajak para guru untuk bekerja sama untuk dapat mewujudkan madrasah unggul dengan mengimplementasi kompetensi masing-masing guru pada bidang pelajarannya dan pelaksanaan pelayanan administrasi pendidikan yang transparan dan akuntabel.

5). Madrasah Aliyah Nu>r Anna>s DDI Tompo Bulu

Madrasah Aliyah Nu>r Anna>s DDI Tompo Bulu, (selanjutnya disebut MA DDI Nu>r Anna>s saja). MA DDI Nu>r Anna>s didirikan pada tahun 2012, dipimpin oleh seorang perempuan yang bernama Nasrah, S.Pd.I., sekaligus sebagai pendiri MA DDI Nu>r Annass. Madrasah ini terletak di Desa Tompo Bulu, sekitar $30 \mathrm{Km}$ dari ibu kota Kecamatan Libureng (Camming), atau sekitar $85 \mathrm{~km}$ dari kota Watampone. Madrasah ini memiliki siswa berjumlah 63 orang dan 13 orang guru. Madrasah ini masih tergolong madrasah baru, walaupun demikian MA DDI Nu>r Anna>s, aktif menjalankan proses pembelajaran dan mengikuti ajang lomba, baik di tingkat Kecamatan maupun di tingkat Kabupaten. Yang membanggakan walaupun masih tergolong baru, madrasah ini memperoleh nilai akreditasi B.

Perkembangan pembelajaran di MA DDI Nu>r Anna>s, sangat ditentukan oleh guru dan kepala madrasah sebagai pimpinan. Oleh karena itu, untuk memperoleh data tentang kepemimpinan perempuan pada MA DDI Nu>r Anna>s, observasi dan wawancara perlu dilakukan. Utamanya kepada kepala MA DDI Nu>r Anna>s, Ibu Nasrah, S.Pd.I. Adapun materi wawancara 
tetap mengacu kepada item-item pertanyaan yang sudah dipersiapkan sebelumnya, yaitu pedoman wawancara untuk kepala madrasah yang jumlahnya 11 item, berisikan tentang kepemimpinan di Madrasah Aliyah.

Hal yang utama dan pertama yang perlu dikaji lebih jauh adalah tentang persoalan dan gaya kepemimpinan Ibu Nasrah dalam memimpin sebagai kepala madrasah di MA DDI Nu>r Anna>s Tompo Bulu. Kepemimpinan selain mengkaji tentang gaya juga persoalan karakter dan sikap, sehingga tema apapun yang dibicarakan yang berkaitan dengan kepemimpinan, maka arah dan fokus pembahasannya selalu mengarah kepada sikap, karakter dan gaya kepemimpinan seseorang. Sebagaimana yang disampaikan oleh dua pakar leadership dunia, Paul Hershey dan Dwight D Elsenhower, menyatakan bahwa kepemimpinan adalah sebuah kemampuan untuk mempengaruhi perilaku orang lain atau kelompok ke arah pencapaian tujuan organisasi, dan kemampuan untuk memutuskan apa yg harus dilakukan dan mengajak orang lain agar mau melakukannya.

Kepemimpinan itu sifatnya spesifik, khas dan diperlukan bagi situasi khusus. Sebab dalam satu kelompok yang melakukan aktivitas-aktivitas tertentu, dan punya tujuan serta peralatan khusus, pemimpin kelompok dengan ciri-ciri karakteristiknya itu merupakan fungsi dari situasi khusus tadi. Jelasnya sifat-sifat utama dari pemimpin dan kepemimpinannya harus sesuai dan bisa diterima oleh Kelompok atau organisasi yang mengangkatnya jadi pemimpin, serta cocok dengan situasi dan zamannya.

Berkaitan dengan gaya dan karakter kepemimpinan lbu Nasrah, diperoleh data dari hasil wawancara bersama salah satu guru di MA DDI Nu>r Anna>s, Ibu Hj. Nuraeni, S.Pd., sebagai berikut:

Penglaman saya sejak menjadi guru di MA DDI Nu>r Anna>s ini, awal mulanya masih coba-coba namun lambat laun jadi senang, karena bisa mengabdikan diri dalam dunia pendidikan. Kepala madrasah yang 
memimpin disini cukup baik dan sangat membantu kami dalam bekerja, apalagi jika menemukan kesulitan dan masalah. Kepala madrasah sebagai manusia biasa tentunya juga memiliki kelemahan dan kekurangan, namun kami tentunya memaklumi itu, utamanya dalam hal kedisiplinan siswa dan guru, saya melihat masih ada saja siswa yang terlambat masuk ke sekolah, serta guru-guru yang datang terlambat ke madrasah, di sini dibutuhkan ketegasan oleh kepala madrasah, namun kepala madrasah, selalu memberikan kebijakan dengan alasan bahwa kondisi sebagian siswa yang tinggal jauh dari gunung kemudian jalanan yang berbatu-batu dan tidak adanya alat transportasi publik, sehingga mereka harus menggunakan kendaraan beroda dua sendiri, dan tentunya perlu berhati-hati karena jalanan yang sangat terjal, sebagian dari mereka berjalan kaki. Kondisi yang sama juga dialami para guruguru yang tinggal jauh dari lingkungan madrasah, namun walaupun demikian tidak serta merta terjadi konflik dan ketegangan diantara kami, dikarenakan semua dimaklumi dengan kondisi yang ada.

Faktor keberhasilan seorang pemimpin salah satunya tergantung dengan teknik kepemimpinan yang dilakukan dalam menciptakan situasi sehingga menyebabkan orang yang dipimpinnya timbul kesadarannya untuk melaksanakan apa yang dikehendaki. Dengan kata lain, efektif atau tidaknya seorang pemimpin tergantung dari bagaimana kemampuannya dalam mengelola dan menerapkan pola kepemimpinannya sesuai dengan situasi dan kondisi organisasi tersebut.

Pernyataan tersebut di atas sesuai dengan anggapan guru MA DDI Nu>r Anna>s Bapak Abd. Rahim, S.Pd.I., selaku guru mata pelajaran Matematika mengatakan bahwa:

Saya sangat senang menjadi guru ini, karena ini merupakan madrasah yang baru didirikan di kampung saya untuk jenjang Madrasah Aliyah, 
lokasinya sangat dekat dengan rumah saya, hanya berjarak sekitar 100 m. Sebelumnya zaman saya dulu harus pergi bersekolah ke MAN 3 Lapppariaja yang cukup jauh, dan pada saat itu saya harus menumpang menginap di rumah warga selama 6 hari, dan pada setiap sabtu sore balik ke kampung untuk membantu orang tua. Selain itu yang membuat saya senang, yah...karena kepala madrasahnya sangat enerjik dan merupakan warga kampong disini juga. Saya melihat lbu Nasrah sebagai kepala madrasah sangat paham dan mengerti dengan tugastugas dan pekerjaanya, apalagi dengan persoalan administrasi dan pembelajaran di kelas. Mengenai gaya kepemimpinan beliau itu selalu ingin membuat bawahanya dapat mengerti apa yang dikerjakan dan betul-betul hasilnya baik, maka dari itu lbu Nasrah sering mengajarkan kepada kami cara-cara menyusun administrasi yang baik, membuat RPP dan mengajar kepada siswa-siswi.

Jika dilihat model dan gaya kepemimpinan, menurut peter $G$ Northouse mengartikan bahwa kepemimpinan adalah aktivitas untuk mempengaruhi orang-orang supaya diarahkan mencapai tujuan organisasi. Kepemimpinan meliputi proses mempengaruhi dalam menentukan tujuan organisasi, memotivasi perilaku pengikut untuk mencapai tujuan, mempengaruhi untuk memperbaiki kelompok dan budayanya.

Gambaran pengertian di atas menunjukkan bahwa gaya kepemimpinan lbu Nasrah di MA DDI Nu>r Annass adalah gaya kepemimpinan transformasional, selalu menginginkan perubahan kepada bawahanya dan kemajuan dalam bekerja, menegur dan gelisah jika ada kesalahan atau kekeliruan yang dilakukan oleh para staf dan guru-guru di MA DDI Nu>r Annass Tompo Bulu. Gaya transformasional ini tidak hanya menginginkan perubahan dan kemajuan, namun yang lebih penting dari itu adalah kemandirian kepada bawahan dalam bekerja. 
b. Hambatan kepemimpinan perempuan sebagai kepala Madrasah di Kabupaten Bone

Hambatan yang ditemukan dapat dikatakan bahwa hambatan fisik dalam kepemimpinan kepala madrasah perempuan di Kabupaten Bone tetap ada, namun tidak menjadi kendala dalam bekerja dan berprestasi.

1) Hambatan Teologis.

Menurut cerita teologis, perempuan diciptakan dari rusuk laki-laki. Sehingga posisi perempuan berada di bawah bayang-bayang laki-laki. Perempuan tidak dapat berbuat banyak seperti laki-laki. Cerita ini secara psikologis menjadi salah satu faktor penghambat perempuan untuk mengambil peran yang berarti dalam keidupan bermasyarakat. Namun dalam kepemimpinan kepala Madrasah Aliyah perempuan di Kabupaten Bone, hambatan teologis ini tidak ditemukan lagi sebagai hambatan yang berarti.

2) Hambatan Sosial-Budaya.

Pandangan ini melihat perempuan sebagai makhluk yang pasif, lemah, perasa, dan berketergantungan. Sebaliknya laki-laki dinilai sebagai makhluk yang aktif, kuat, cerdas dan mandiri. Pandangan ini pula menempatkan lak-laki secara sosio-kultural lebih tinggi derajatnya dibanding perempuan. Hambatan sosial budaya memang masih ditemukan dalam masyarakat di kabupaten Bone, akan tetapi itu terjadi pada kalangan keluarga yang masih memegang kuat budaya dan tradisi Bugis.

Keluarga merupakan salah satu faktor yang dapat mendukung dan menghambat kepemimpinan kepala Madrasah Aliyah perempuan di Kabupaten Bone. Budaya masyarakat Bugis Bone yang telah berlangsung secara turun temurun, yang menempatkan peran perempuan pada sektor domestik dan laki-laki pada sektor publik, mengakibatkan perempuan berperan ganda. Begitu juga budaya masyarakat yang bersumber dari 
pemahaman agama, khususnya di tingkat lokal turut menjadi faktor yang menghambat lajunya kepemimpinan perempuan. Inilah yang menjadi tantangan dan hambatan kepala Madrasah Aliyah perempuan yang ada di Kabupaten Bone.

Hal ini sesuai dengan hasil wawancara dengan salah satu kepala Madrasah Aliyah perempuan yang ada di Kabupaten Bone, yaitu Ibu Nurlela, S.Ag, M.Pd.I., sebagai berikut:

Menjadi kepala Madrasah Aliyah perempuan banyak suka dukanya, kita dituntut untuk menyelesaikan berbagai masalah yang ada di madrasah. Disamping itu kita juga dituntut untuk menyelesaikan pekerjaan rumah tangga. Karena anggapan orang di rumah bahwa pekerjaan rumah seperti memasak, menyapu, mencuci itu adalah pekerjaan perempuan/ibu. Suami saya kadang menuntut untuk disiapkan makanannya, pakaiannya, begitu pula anak-anak saya. Mana lagi pekerjaan di kantor bertumpuk. Kadang saya pusing, mau kerja yang mana dulu. Kalau hal ini terjadi saya kadang minta bantuan kepada keluarga dekat saya untuk menyelesaikan pekerjaan rumah. Pekerjaan di kantor saya selesaikan sendiri karena itu merupakan tanggung jawab saya.

Sejarah memang pernah menempatkan perempuan pada posisi kedua di bawah laki-laki, tetapi itu hanya faktor budaya atau tradisi yang tendensius secara ekstrem. Setelah Nabi Muhammad saw. membawa Islam, maka perempuan dimuliakan dan dipertemukan kembali dengan martabatnya yang selama ini seolah terinjak-injak oleh laki-laki. Hingga hari ini tradisi yang diskriminatif itu masih berpengaruh kuat di sebagian wilayah Nusantara. Maka tidak heran jika dikuantifikasi maka angka-angka masih berpihak kepada kaum laki-laki, dengan beberapa pengecualian, misalnya tingkat partisipasi sekolah menengah yang semakin memihak kepada siswa perempuan. 
Menurut D.J. Wood yang dikutip oleh Muhammad Yusuf, Kepemimpinan keperempuan merupakan salah satu tema yang menjadi perhatian pemerhati dan aktivis jender. Persoalan kesetaraan antara laki-laki dan perempuan merupakan topik yang terus diperdebatkan, karena jender dilihat dari berbagai perspektif, motif, dan kepentingan.

Jender berkaitan dengan persepsi dalam suatu masyarakat bahwa aktivitas, sikap, dan perilaku yang boleh atau tidak boleh dilakukan baik oleh laki-laki atau perempuan. Selanjutnya jender merupakan hasil konstruksi sosial terhadap apa yang disebut maskulin dan feminim. Perbedaan biologis tidak bisa dijadikan pembeda kecuali struktur anatomi tubuh, reproduksi, dan untuk mengenali jenisnya.

Dalam tradisi Bugis, istri disebut indo'ana'. Kata “indo' ana'” berarti "ibu". Kata "ibu" mengandung kata penuh harapan dan kedamaian. Istilah "indo ana" bukan hanya digunakan untuk istri yang memiliki anak, melainkan juga untuk istri yang belum memiliki anak. Sementara suami bekerja mencari nafkah dan biaya keluarga dibantu oleh istrinya dalam batas-batas yang wajar (sitinaja) disebut sibaliperri' (saling membantu, bermitra). Penafsiran mereka sekaligus menempatkan suami sebagai penanggung-jawab mencari nafkah (sappa' laleng atuwong, atau sappa' dalle'). Perempuan dalam wilayah rumah tangga saja sebagai ibu (indo' ana') kewajibannya mengasuh anak, menjadi sumber rasa damai, memasak, mencuci, dan berbelanja keperluan keluarga.

Penafsiran itulah yang mendasari sehingga kaum laki-laki suku Bugis menganggap pekerjaan rumah adalah pekerjaan perempuan. Malah yang ekstrim menganggap seorang laki-laki yang mengerjakan pekerjaan rumah disebut bencong (Laki-laki yang menyerupai perempuan). Hal ini sesuai dengan hasil wawancara dengan Ibu Murniati, S>.Ag, M.Pd.I., kepala MA al-Juna>idiyah Biru sebagai berikut: 
Dalam masyarakat Bugis dikenal sebuah adat budaya yang disebut sipakatau (saling menghargai) dan sipakalebbi (saling menghormati). Budaya sipakatau dan sipakalebbi' itu tidak dimaksudkan untuk jenis kelamin tertentu, melainkan untuk laki-laki dan perempuan. Akan tetapi dalam kenyataan sehari-hari budaya Bugis sangat menghargai kaum laki-laki. Inilah yang menjadi tantangan eksternal sebahagian kepala Madrasah Aliyah perempuan yang ada di Kabupaten Bone. Mereka memiliki peran ganda yaitu peran domestik sebagai ibu rumah tangga dan peran publik sebagai kepala Madrasah Aliyah.

3) Hambatan Sikap Pandang

Hambatan sikap pandang yang antara lain dimunculkan oleh pandangan dikotomis antara tugas perempuan dan laki-laki, pada dasarnya sudah terkikis pada kelas masyarakat yang berpendidikan. Namun beda halnya pada masyarakat yang berpendidikan rendah sebagian masih menjalankan sikap pandang tentang pembagian kerja antara laki-laki dan perempuan. Hal ini sesuai dengan hasil wawancara dengan lbu Nasrah, S.Pd.I. sebagai berikut:

"Sebagai kepala madrasah saya tidak pernah mendapat larangan dari suami saya sekaitan dengan tugas sebagai kepala madrasah. Bahkan suami saya sangat mendukung aktifitas dan profesi saya sebagai guru dan kepala madrasah. Bahkan suami saya sangat membantu dalam berbagai hal urusan saya dan urusan rumah tangga lainya, seperti mengantarkan dan menjemput saya ke madrasah, membantu memasak dan urusan-urusan rumah tangga lainya."

Perempuan dinilai sebagai makhluk rumah, sedangkan laki-laki dilihat sebagai makhluk luar rumah. Pandangan dikotomis seperti ini boleh jadi telah membuat perempuan merasa risih keluar rumah, dan pandangan bahwa 
tugas-tugas kerumah tanggaan tidak layak digeluti laki-laki. Pandangan ini sudah tidak ditemukan oleh kepala Madrasah Aliyah di Kabupaten Bone.

4) Hambatan Historis.

Hambatan historis muncul disebabkan kurangnya nama perempuan dalam sejarah dimasa lalu yang tampil sebagai pemimpin. Hal ini dipakai untuk membenarkan ketidak mampuan perempuan untuk berkiprah seperti halnya laki-laki. Namun hambatan tersebut di atas tidak berlaku bagi kepala Madrasah Aliyah perempuan yang ada di Kabupaten Bone, bahkan kepala Madrasah Aliyah perempuan di Kabupaten Bone, sangat di hargai dan di tokohkan di lingkungan dimana mereka berada. Sebagaimana pada bab satu telah dijelaskan bahwa dalam sejarah kerajaan Bone, telah mendudukkan tujuh kali perempuan sebagai raja, ini membuktikan bahwa perempuan secara historis sangat dihargai di Kabupaten Bone.

\section{Kontribusi Kepemimpinan Perempuan Sebagai Kepala Madrasah} Aliyah di Kabupaten Bone

a. Meningkatkan mutu madrasah

Salah satu kontribusi kepala Madrasah Aliyah perempuan di Kabupaten Bone, dalam bidang pendidikan yaitu meningkatkan mutu madrasah. Hadirnya perempuan sebagai kepala madrasah dalam dunia pendidikan yang digeluti, sasaran akhir yang diharapkan adalah terjadinya peningkatan mutu. Upaya peningkatan mutu pendidikan di madrasah yang ada di kabupaten Bone, terus dilakukan, sehingga slogan "madrasah hebat, madrasah bermartabat" dapat tercapai. Jika madrasah maju dan berkembang, serta memperoleh kepercayaan masyarakat, maka masyarakat akan memilih madrasah sebagai lembaga pendidikan terbaik untuk anakanaknya. 
Hal ini dapat dilihat dari usaha kepala MA al-Juna>idiyah\} Biru. Dalam sesi wawancara bersama Ibu Andi Ilmiah Makmur, S.Ag, M.Pd.I., salah satu guru MA al-Juna>idiyah\} Biru mengatakan:

Di bawah kepemimpinan ibu Murniati, S.Ag, M.Pd.I., akreditasi MA alJuna>idiyah\} Biru meningkat dari akreditasi C menjadi akreditasi A. 27 tahun lamanya MA al-Juna>idiyah\} Biru dipimpin oleh kepala madrasah laki-laki, tetapi nilai akreditasi madrasah hanya mampu meraih nilai $\mathrm{C}$. Begitu pula dengan jumlah siswa, pada saat kedatangan ibu Murniati, S.Ag, M.Pd.I., sebagai kepala madrasah hanya berjumlah 20 orang, tetapi sekarang jumlah siswa sudah mencapai 184 orang.

Empat kali pergantian kepala madrasah di MA al-Juna>idiyah\} Biru, mulai tahun 1987 sampai tahun 2014, akreditasi madrasah tidak pernah berubah dari akreditasi C. Empat kepala madrasah laki-laki yang memimpin MA al-Juna>idiyah\} Biru tidak mampu mengangkat nilai akreditasi madrasahnya dari nilai C. Pada tahun 2014 MA al-Juna>idiyah\} Biru dipimpin oleh seorang perempuan yang bernama ibu Murniati, S.Ag, M.Pd.I. Kepemimpinan Ibu Murniati, S.Ag, M.Pd.I., membawa banyak perubahan di MA al-Juna>idiyah\} Biru. Selama 27 tahun nilai akreditasi $C$ di sandang oleh MA al-Juna>idiyah\} Biru, meningkat menjadi nilai $A$ hanya dalam jangka waktu 3 tahun, di bawah kepemimpinan seorang perempuan.

Hal ini juga terjadi di MAN 4 Bone, selama kepemimpinan bapak Drs. H. Abdul Latif M.Pd., nilai akreditasi MAN 4 Bone hanya bisa meraih nilai B. Setelah kepemimpinan dipegang oleh ibu Dra. Hj. Adila, nilai akreditasi MAN 4 Bone berubah menjadi A. Hal ini membuktikan bahwa kepala Madrasah Aliyah perempuan yang ada di Kabupaten Bone, mampu meningkatkan mutu madrasah yang dipimpinnya.

Nilai akreditasi madrasah menunjukkan mutu madrasah tersebut. Karena nilai akreditasi diperoleh berdasarkan penilaian 8 Standar Nasional 
Pendidikan (SNP), yaitu: standar isi, standar proses, standar kompetensi lulusan, standar pendidikan dan tenaga kependidikan, standar sarana dan prasarana, standar pengelolaan, standar pembiayaan dan standar penilaian pendidikan.

Mutu pendidikan merupakan derajat keunggulan sebuah produk atau pelayanan. Sebuah produk yang bersaing dengan produk lainnya atau suatu pelayanan jasa bersaing dengan pelayanan jasa lainnya, yang terpilih adalah pelayanan yang memiliki tingkat keunggulan. Madrasah Aliyah di Kabupaten Bone diharapkan mampu bersaing dengan sekolah menengah atas (SMA), sehingga Madrasah Aliyah menjadi pilihan masyarakat untuk menyekolahkan anaknya.

Produk atau pelayanan jasa yang lebih unggul adalah produk atau pelayanan jasa yang bermutu. Mutu merupakan kesempatan ajang berkompetisi sangat berharga, karena itu munculnya kompetitor merupakan sebuah wahana untuk meningkatkan mutu produk layanan jasa. Dengan demikian, mewujudkan pendidikan dengan mengikuti standar mutu adalah penting, sebagai bagian dari produk layanan jasa. Standar yang menjadi acuan pendidikan dasar dan menengah, di mana Madrasah Aliyah termasuk di dalamnya.

\section{b. Meningkatkan prestasi siswa}

Kepala Madrasah Aliyah perempuan yang ada di Kabupaten Bone, juga berkontribusi dalam meningkatkan prestasi siswa. Hal ini dapat di lihat dari hasil wawancara dengan salah satu guru Madrasah Aliyah yang kepala madrasahnya adalah perempuan. Berikut hasil wawancara salah seorang guru MAN 4 Bone, yaitu ibu Suhaeni, S.Pd., mengatakan:

Dulunya MAN 4 Bone ketika masih berstatus kelas jauh, dari MAN 3 Bone yang kepala madrasahnya laki-laki, madrasah ini kurang begitu 
berkembang. Jumlah siswanya sangat sedikit hanya sekitar 60 orang. Kemudian jumlah gurunya juga masih mengharap dari MAN 3 Bone sebagai induknya. Kondisinya susah berkembang karena kepemimpinan yang kurang maksimal, namun setelah madrasah ini ditingkatkan statusnya menjadi mandiri dengan kepemimpinan sendiri, alhmadulillah sejak tahun 2010 resmi menjadi MAN 4 Bone dan yang diangkat menjadi kepala madrasah adalah seorang perempuan yaitu ibu Dra. Hj. Adila. Sekarang jumlah siswa mencapai 310 orang, guru 32 orang yang terdiri dari 23 perempuan 9 laki-laki dan staf administrasi 7 orang, 5 orang perempuan 2 orang laki-laki. Sejak itulah mulai ada perkembangan jumlah siswa dan bangunan serta jumlah guru dan staf administrasi di MAN 4 Bone. Peningkatan jumlah siswa juga didukung oleh peningkatan kualitas pendidikan yang diberikan kepada masyarakat. Sejak ibu Adila jadi kepala madrasah, banyak prestasi yang diraih oleh siswa baik prestasi akademik maupaun prestasi non akademik. Nilai akreditasi madrasah juga meningkat dari akreditasi B menjadi akreditasi $\mathrm{A}$.

Dari data wawancara di atas dapat diketahui bahwa kepala Madrasah Aliyah perempuan di Kabupaten Bone, mempunyai peran penting dalam meningkatkan prestasi siswa Madrasah Aliyah di Kabupaten Bone. Pengembangan madrasah yang dilakukan bukan hanya dari segi kuantitas jumlah siswa, guru dan sarana prasarana tapi juga peningkatan prestasi siswa baik prestasi akademik maupun prestasi non akademik.

c. Meningkatkan animo masyarakat.

Masyarakat di Kabupaten Bone sudah mulai membuka mata melihat keunggulan-keunggulan madrasah di banding sekolah, sehingga masyarakat tidak lagi memandang sebelah mata madrasah, khususnya Madrasah Aliyah yang ada di Kabupaten Bone. Hal ini dapat di lihat dari animo masyarakat dalam memasukkan anaknya untuk belajar di madrasah. Dari tahun ke tahun 
terjadi peningkatan jumlah siswa Madrasah Aliyah di Kabupaten Bone. Khusus Madrasah Aliyah yang dipimpin oleh kepala madrasah perempuan, yaitu MAN 4 Bone, semasa dipimpin oleh kepala madrasah laki-laki yaitu Bapak Drs. H. Abdul Latif, M.Pd., siswanya hanya berjumlah 60 orang. Ketika MAN 4 Bone dipimpin oleh lbu Dra. $\mathrm{Hj}$. Adila seorang perempuan, masyarakat mulai berlomba-lomba memasukkan anaknya untuk belajar di MAN 4 Bone. Sekarang siswa MAN 4 Bone berjumlah 310 orang. Hal ini dapat dilihat dari hasil wawancara salah seorang guru MAN 4 Bone, sebagai berikut:

Dulunya MAN 4 Bone ketika masih berstatus kelas jauh, dari MAN 3 Bone yang kepala madrasahnya laki-laki, madrasah ini kurang begitu berkembang. Jumlah siswanya sangat sedikit hanya sekitar 60 orang. Kemudian jumlah gurunya juga masih mengharap dari MAN 3 Bone sebagai induknya. Kondisinya susah berkembang karena kepemimpinan yang kurang maksimal, namun setelah madrasah ini ditingkatkan statusnya menjadi mandiri dengan kepemimpinan sendiri, alhmadulillah sejak tahun 2010 resmi menjadi MAN 4 Bone dan yang diangkat menjadi kepala madrasah adalah seorang perempuan yaitu ibu Dra. Hj. Adila. Sekarang jumlah siswa mencapai 310 orang, guru 32 orang yang terdiri dari 23 perempuan 9 laki-laki dan staf administrasi 7 orang, 5 orang perempuan 2 orang laki-laki. Sejak itulah mulai ada perkembangan jumlah siswa dan bangunan serta jumlah guru dan staf administrasi di MAN 4 Bone. Peningkatan jumlah siswa juga didukung oleh peningkatan kualitas pendidikan yang diberikan kepada masyarakat. Sejak ibu Adila jadi kepala madrasah, banyak prestasi yang diraih oleh siswa baik prestasi akademik maupaun prestasi non akademik. Nilai akreditasi madrasah juga meningkat dari akreditasi $B$ menjadi akreditasi A. 
Begitu pula di MA al-Juna>idiyah\} Biru, selama 4 kali pergantian kepala madrasah yang semuanya dipimpin oleh kepala madrasah laki-laki jumlah siswa terbanyak hanya 20 orang. Ketika MA al-Juna>idiyah\} Biru dipimpin oleh seorang perempuan yaitu Ibu Murniati, S.Ag, M.Pd., masyarakat mulai tertarik memasukkan anaknya untuk belajar di MA alJuna>idiyah\} Biru. Sebagaimana hasil wawancara dengan salah satu guru MA al-Juna>idiyah\} Biru, sebagai berikut:

Di bawah kepemimpinan Ibu Murniati, S.Ag, M.Pd.I., akreditasi MA AlJuna>idiyah\} Biru meningkat dari akreditasi C menjadi akreditasi A. 31 tahun lama MA al-Juna>idiyah\} Biru dipimpin oleh kepala madrasah laki-laki, tetapi nilai akreditasi madrasah hanya mampu meraih nilai $\mathrm{C}$. Begitu pula dengan jumlah siswa, pada saat kedatangan ibu Murniati, S.Ag, M.Pd.I., sebagai kepala madrasah hanya berjumlah 20 orang, tetapi sekarang jumlah siswa sudah mencapai 184 orang.

Dari data tersebut di atas menunjukkan bahwa kepala Madrasah Aliyah perempuan di Kabupaten Bone, berkontribusi meningkatkan animo masyarakat terhadap madrasah. Dengan demikian kontribusi perempuan sebagai kepala Madrasah Aliyah, dalam bidang pendidikan adalah memberikan pelayanan yang terbaik kepada masyarakat yang anaknya di sekolahkan di Madrasah Aliyah, mulai dari peningkatan prestasi siswa baik prestasi akademik maupun prestasi non akademik.

Pengelolaan pendidikan yang menekankan kemandirian madrasah, merupakan penjabaran dari otonomi pendidikan di madrasah. Pemberian otonomi pendidikan kepada madrasah merupakan usaha untuk meningkatkan mutu pendidikan secara luas, sehingga madrasah dapat leluasa mengelola sumber daya dengan mengalokasikannya sesuai prioritas kebutuhan serta tanggap terhadap kebutuhan masyarakat sekitar. 


\section{DAFTAR PUSTAKA}

Abu, Sri Nurhidah. "Pembinaan Guru Oleh Kepala Sekolah dalam Pengelolaan Pembelajaran di Sekolah Dasar." Bahana Manajemen Pendidikan 2.1 (2014), h. 704-712. Bahana Manajemen Pendidikan, 2014 - ejournal.unp.ac.id

2 Abustang, SE, S.Pd, pada Tanggal 10 februari 2018

3 Affandi, Moch. "Faktor-faktor yang mempengaruhi penduduk lanjut usia memilih untuk bekerja", Journal of Indonesian Applied Economics 3.2 https://www.researchgate.net/318641044. 2009.

4

al-'Asqa $>$ la $>$ ni, Abi $>$ al-Fadl Ahma $>$ d bin Ali> bin Hajr $>$. Fas/l al-Kita $>b$ fi> Tariskh Ibn al-Khatta>b. al- Is/a>bah fi> Tamyisz al-S/aha>bah, alJuz al-Awal; Beirut: Dar al-Fikr, tth.

5 al-Damasyqi, Al-Ha>fi>z Ibnu Kas\{i>r Imam Abi> Al-Fida'. Tafsi>r AlQur'a>n al-'Azi>m. Jilid II Beiru>t: Da>r al-Fikr, 1992.

$6 \quad$ Ali, Mohammad. "Pendidikan Untuk Pembangunan Nasional: Menuju Bangsa Indonesia yang Mandiri dan Berdaya Saing Tinggi", Grasindo. http://www.worldcat.org/title/ pendidikan-untuk-pembangunan-nasionalmenuju-bangsa-indonesia-yang-mandiri-dan-berdaya-saing- tinggi / oclc/ 697293665, 2009.

7 Al-Khurasany, Ahmad bin Syu'aib. Sunan al-Nasa i. Jilid. 2: Beirut: Dar al-Fikr, tth.

8 Al-Tirmidzi, Muhammad Bin Isa Bin Surah. Sunan at-Tirmidzi, (Cet. II; Riyadh: Maktabah al-Ma'aarif Linnasyri Wattauzi, 2008 H/1429M, 2000 $\mathrm{M} / 1421 \mathrm{H}$.

9 al-Zamakhsya>ri, al-Zamakhsya>ri> 'Abd al-Qa>sim Mahmu>d ibn Muhammad ibn 'Umar. al-Kasysyaf 'an Haqa'iqi Gawamidit Tanzil wa Uyanil Aqawil fi Wujuhit Ta'wil. Beirut: Dar al-Fikr, tth.

10 Amin, Qāsim, The liberation of women: And, the new woman: Two documents in the history of Egyptian feminism. American Univ in Cairo Press, 2000.

11 Amin, Qasim. Tahrir al-Mar'at. Cairo: Dâr al-Ma'ârif, 1970.

12 Anisari, Anisari, Eri Purwanti, and Moh Masrur. "Strategi Kepala Sekolah Dalam Meningkatkan Mutu Pembelajaran Di Smp Nurul Islam Kelurahan Garuntang Kecamatan Bumi Waras Kota Bandar Lampung." Jurnal Manajemen Pendidikan Islam Al-Idarah 1.1 (2017). Pendidikan Islam Al ..., 2017 - ejurnal-stitpringsewu.ac.id

13 Anshor, Maria Ulfah. "Tantangan Kepemimpinan Perempuan di Tingkat Lokal", $\quad Y$ in Yang 3.1 ejournal.iainpurwokerto.ac.id/index.php/yinyang/article/view/189/160. 2008. 
14 Apriliya, Seni. "Manajemen Kelas untuk Menciptakan Iklim Belajar yang Kondusif." Bandung: Visindo (2007).http://Bandung: Visindo, 2007

15 Badan Pusat Statistik Kabupaten Bone dalam Angka 2016, Katalog: 1102001.7311. http:///bonekab.bps.go.id/v3/pdf_publikasi/Kabupaten Bone-Dalam-Angka-2016.pdf . 2016.

16 Baidowi, Ahmad. "Tafsir Feminis: Kajian Perempuan dalam al-Qur'an dan Para Mufasir Kontemporer", Bandung Nuansa https://journal.uinsgd.ac.id/index.php/ jw/article/ download/ 780/937. 2005.

17 Bawani, Imam. Metodologi Penelitian Pendidikan Islam. Cet. I; Surabaya: Khazanah IImu, 2016.

18 Bella, Anna. "Muslim Women's Online Discussions of Gender Relations in Islam", Journal of Muslim Minority Affairs, Vol. 30, No. 3, (September 2010), h. 33. SSN 1360-2004 print /ISSN 1469-9591 online/10/030425-11\# 2010 Institute of Muslim Minority Affairs DOI: www.tandfonline.com/doi/abs/10.../13602004.2010.515827 . 2010.

19 Budiman, Kris. Feminis Laki-Laki dan Wacana Gender . Cet. I; Jakarta: Indonesiatera, 2000.

20 Bungi, Burhan. Analisa Data Penelitian Kualitatif, Pemahaman Filosofis dan Metodologis Kearah Penguasaan Modal Aplikasi. Jakarta: Raja Grafindo Persada, 2003.

21 Cheung, M. Fanny, berjudul. "Women At The Top: Powerful Leaders Define Success As Work And Family In A Culture Of Gender. 2017 https: //www.ncbi.nlm.nih.gov/ pubmed/20350017. 2017.

22 Creswell, John W.. Qualitative, Quantitative, and mixed Methods Approaches, Second Edition. Lihat juga: Kirk dan Miller Taylor, Moleong Lexy J. Moleong, Metodologi Penelitian Kualintatif. Bandung: Remaja Rosdakarya, 2000.

23 D.M, M.Ide Said. Kamus Bahasa Bugis-Indonesia (Pusat Pembinaan dan Pengembangan Bahasa, Departemen Pendidikan dan Kebudayaan, indonesia/oclc/5219953. 1985.

24 Danim, Sudarwan. Motivasi Kepemimpinan dan Efektivitas Kelompok. Cet. VI; Jakarta: Rineka Cipta, 2004.

25 Darmadji, Ahmad. "Implementasi Total Quality Management sebagai Upaya Peningkatan Mutu Pendidikan di MAN Model Yogyakarya." EL TARBAWI 1.2 (2013), h. 181-200. EL TARBAWI, 2013 - jurnal.uii.ac.id

26 Daryanto, Administrasi Pendidikan, (Jakarta: Rineka Cipta, 2001).

27 Deborah, Deborah. "You Just Don't Understand: Women And Men In Conversation", 1St: London: Virago, https: //www.researchgate.net/file.PostFileLoader.html?id 1991. 
28 Dwiwibawa, F. Rudi dan Theo Riyanto. "Siap Jadi Pemimpin? Latihan Dasar Kepemimpinan", Jurnal Pendidikan Kanisius. anfisipunej16037.http://web.unej.ac.id/2017/12/04/tipe-tipe-pemimpin/ 2008.

29 E; Martini, Mulyoutami, Khususiyah N, Isnurdiansyah, Suyanto S. "Seri Agroforestri Dan Kehutanan Di Sulawesi: Gender, Mata Pencarian Dan Lahan Di Sulawesi Selatan Dan Sulawesi Tenggara", Working Paper 167. Bogor, Indonesia: World Agroforestry Centre (ICRAF) Southeast Asia Regional Program. 78p. DOI: 10.5716/WP13043.PDF.(2013) Published by the World Agroforestry Centre Southeast Asia Regional Program. www.worldagroforestry.org/region/ southeast-asia. PO Box 161, Bogor 1600 Indonesia. 2010.

30 Elizabeth, Roosganda. "Pemberdayaan Wanita Mendukung Strategi Gender Mainstreaming dalam Kebijakan Pembangunan Pertanian di Perdesaan.", Forum penelitian agro ekonomi. Vol. 25. No. 2 eriset.unimus.ac.id/index.php/ psn12012010/ article/ viewFile/ 411/460. 2016.

31 Emawati, Eva. Pengaruh Output Sertifikasi Terhadap Kualitas Guru Dalam Mengajar Pai Di Madrasah Ibtidaiyah Nurul Ikhlas Tambak Sawah Sidoarjo. Diss. UIN Sunan Ampel Surabaya, 2011.

32 Eva, Roosganda. "Peran Ganda Wanita Tani Dalam Mencapai Ketahanan Pangan Rumah Tangga Di Pedesaan", Iptek Tanaman Pangan. pangan.litbang.pertanian.go.id/files/05-Roosganda.pdf 3.1. 2015.

33 Fajarini, Ulfah. "Peranan kearifan lokal dalam pendidikan karakter." SOSIO-DIDAKTIKA: Social Science Education Journal 1.2 (2014), h. 123-130. SOSIO-DIDAKTIKA: Social Science Education ..., 2014 journal.uinjkt.ac.id

34 Fatkhurrohman, Azhar. "Efektivitas Kepemimpinan Kepala Madrasah Perempuan di MI Ma'arif NU 1 Kracak kecamatan Ajibarang Kabupaten Bantumas". Disertasi tidak diterbitkan. IAIN Purwokerto, 2017.

35 Ford, Michele and Lyn Parker, eds. "Women And Work In Indonesia", Vol. 5. Routledge. https: //www.scribd.com/doc/Women-and-Work-inIndon. 2008.

36 Ginting, Bersita. "Hubungan budaya organisasi sekolah dan kepemimpinan kepala sekolah dengan kinerja guru SMA Negeri Di Kota Binjai." Jurnal Tabularasa 8.01 (2011). - Jurnal Tabularasa, 2011 - digilib.unimed.ac.id

37 Gunawan, Imam. Metode penelitian kualitatif. Cet. I; Jakarta: Bumi Aksara 2013.

38 Harahap, Julismin. "Analisis Makro Tenaga Kerja Perempuan Dalam Pembangunan di Indonesia 1980-2010", Publikauma: Jurnal Administrasi Publik Universitas Medan Area 2.1. 
39ojs.uma.ac.id/index.php/publikauma/indexISSN: 2549-9165 (Cetak) ISSN: 2580-2011 (Online) 2014.

40 Harahap, Syahrin. Metodologi Studi Tokoh Pemikiran Islam. Cet. VI; Jakarta: Prenadamedia Group, 2011.

41 Hershey, Paul and Kenneth Blanchard. "Management of organizational behavior", Prentiss Hall, England Cleft, NJ (1977), dalam Faisal Ismail. "Keteladanan dalam konteks kepemimpinan nasional dan realitas kemajemukan bangsa", UNISIA 52. 2016.

42 HF Smith, Paul Wessel and Walter. "Free software helps map and display data: Eos, Transactions American Geophysical Union 72.4. 1991.

43 Indonesia, Presiden Republik. "Undang-undang Republik Indonesia nomor 20 tahun 2003 tentang sistem pendidikan nasional." (2003).

44 Indonesia, PRESIDEN REPUBLIK. Peraturan Pemerintah Republik Indonesia nomor 19 tahun 2005 tentang standar nasional pendidikan. Departemen Pendidikan Nasional Republik Indonesia, 2005. http:// repository.mdp.ac.id

Irianto, Jusuf. "Perempuan dalam Praktek Manajemen Sumber Daya Manusia", Masyarakat Kebudayaan dan Politik 20. https://ajournal.id/Perempuan-dalam-Praktek-Manajemen-SumberDaya-Manusia. 2007.

46 Iskandar, Uray. "Kepemimpinan Kepala Sekolah Dalam Peningkatan Kinerja Guru", Jurnal Visi Ilmu Pendidikan. jurnal.untan.ac.id. Home. Vol 10, No 1 (2013). Iskandar. 10.12013.

47 Ismail, Nurjannah. "Perempuan Dalam Pasungan: Bias Laki-Laki Dalam Penafsiran", LKiS Pelangi Aksara, www.lkis.co.id/produk-720perempuan dalam pasungan bias lakilaki dalam penafsiran.html. 2003.

48 Karau, Alice H Eagly and Steven J. "Role Congruity Theory of Prejudice to ward Female Leaders", Psychological review 109.3 https://www.ncbi.n/m.nih.gov/pubmed/12088246 www.psycnet.apa.org. 2002.

49 Kementerian Pemberdayaan Perempuan dan Perlindungan Anak. peraturan.go.id/kementerian-pemberdayaan-perempuan-danperlindungan-anak.html 2015.

50 Khotimah, Khusnul. "Diskriminasi gender terhadap perempuan dalam sektor pekerjaan", Yin Yang 4.1 ejournal.iainpurwokerto.ac.id/index.php/yinyang/article/view/226 2009.

51 Koontz, Harold and Cyril O'Donnell, (1984). "State That Leadership Is Influencing People The Follow In The Achivement Of A Common Goal Handbook of Leadership", Franklin, Stephen G., and George R. Terry. "Principios De Administración Compaia", (2000), Gibson, Rowan. "Rethinking The Future: Rethinking Business, Principles, Competition, Control \& Complexity, Leadership, Markets And The Worl", Nicholas 
Brealey Publishing, https://profs.info.uaic.ro/ avitcu/FII\%2020152016/RF.pdf .2011.

52 Kurniawan, Yudha dan Tri Puji Hindarsih. Character Building Membangun Karakter Menjadi Pemimpin. Cet. I; Yogyakarta: Pro U Media, 2013.

53 Luthfi, Asma dan Sjafri Sairin. Aji Modereng: Studi Tentang Haji Dan Perubahan Sosial Budaya Dalam Masyarakat Bugis. Diss. Universitas Gadjah Mada, 2006.

54 Mattulada, Latoa. Satu Lukisan Analitis terhadap Antropologi Politik Orang Bugis. Gajah Mada University Press, 1985

55 M Bass, Bernard and Ruth Bass. "The Bass Handbook of Leadership: Theory, Research, and Managerial Applications", Simon and Schuster . www.simonandschuster.com/.../The-Bass-Handbook-of-Lea, 2009,

56 M File Jr, Thomas, et al. "FOCUS 1: A Randomized, Double-Blinded, Multicentre, Phase III Trial of The Efficacy and Safety of Ceftaroline Fosamil Versus Ceftriaxone In Community-Acquired Pneumonia" Journal of Antimicrobial Chemotherapy 66.suppl_3. https://www.amazon.com/Bass...Handbook-Leadership-Appl 2011.

57 Machali, Imam. MANAJEMEN MUTU SISTEM PEMBELAJARAN MADRASAH: Kontribusi Kepemimpinan Kepala Madrasah, Kompetensi Guru, Sarana Prasarana, dan Budaya Madrasah Terhadap Mutu Pembelajaran dan Dampaknya Terhadap Kepuasan Siswa di Madrasah Aliyah Swasta di Kota Yogyakarta Tahun 2009/2010. Diss. Universitas Pendidikan Indonesia, 2011.

58 Machali, Imam."Manajemen Mutu Sistem Pembelajaran Madrasah: Kontribusi Kepemimpinan Kepala Madrasah, Kompetensi Guru, Sarana Prasarana, dan Budaya Madrasah Terhadap Mutu Pembelajaran dan Dampaknya Terhadap Kepuasan Siswa di Madrasah Aliyah Swasta di Kota Yogyakarta Tahun 2009/2010", http://repository.upi.edu. Diss. Universitas Pendidikan Indonesia, 2010.

59 Maduratna, Munika. "Peranan Kepemimpinan Kepala Sekolah dalam Meningkatkan Efektivitas Kerja Guru dan Pegawai di Sekolah Dasar Negeri 015 Samarinda",Journal Administrasi Negara. ejournal.an.fisipunmul.ac.id/.../ejournal_monika_genap\%20. 02-24-13-12-25-13.pdf. 2013.

60 Mahmud, Eka. "Motif Penyelenggaraan Pendidikan Islam dan Implikasinya pada Pola Manajemen dan Kepemimpinan, www.journal.iain-samarinda.ac.id. 2012.

61 Mahmud, Muchammad Eka. "Motif Penyelenggaraan Pendidikan Islam dan Implikasinya pada Pola Manajemen dan Kepemimpinan", Dinamika Ilmu: Jurnal Pendidikan. journal.iain-samarinda.ac.id/index.php/ dinamika_ilmu/article/view/60 12.2. 2012.

62 Majid, Fitria dan Herniwati Retno Handayani. "Faktor-Faktor Yang 
Mempengaruhi Keputusan Perempuan Berstatus Menikah Untuk Bekerja (Studi Kasus: Kota Semarang)", Diss. Fakultas Ekonomika dan Bisnis 2012.

63 Mangunsong, Frieda. "Faktor Intrapersonal, Interpersonal, Dan Kultural Pendukung Efektivitas Kepemimpinan Perempuan Pengusaha Dari Empat Kelompok Etnis Di Indonesia", Makara, Sosial Humaniora.www.sosialhumaniora.staff.ui.ac.id".13.1. 2009.

64 Mattulada. Latoa Satu Lukisan Analitis Terhadap Antropologi Politik Orang bugis. Yogyakarta: Gadja Mada University Press, 1985

65 Moleong, Lexy J. Metode Kualitatif. Bandung: Remaja Rosdakarya, 2004.

66 Muhaimin, M. A. Manajemen Pendidikan (Aplikasinya dalam Penyusunan Rencana Pengembangan Sekolah/Madrasah). (Cet.l: Prenada Media, 2015).

67 Muhammad, Ardison."Iran Sejarah Persia \& Lompatan Masa Depan Negeri Kaum Mullah", https://www.belbuk.com/iran-sejarah-persialompatan-masa-depan-negeri-kaum-mull. 2010.

68 Muhammad, KH Husein. "Fiqh Perempuan: Refleksi Kiai Atas Wacana Agama Dan Gender", PT LKiS Pelangi Aksara digilib.uinsuka.ac.id/1/BAB\%20l\%2C\%20V\%2C\% 20DAFTAR\% 20PUSTAKA.pdf. 2001.

69 Muhibbin, Ahmad. "Pengembangan Strategi Pembelajaran Inovatif dengan Pendekatan Active Learning." Materi Diklat Peningkatan Kompetensi Kepala Madrasah Jenjang Pendidikan Dasar dan Menengah https://scholar.google.co.id/scholar?start=10\&q=pembelajaran+dan+ke pala+madrasah\&hl=id\&as_sdt $=0,5$

70 Muhsin. "Kontribusi Penafsiran Sahabat Perempuan, Kajian Atas Penafsiran Aisyah Dalam Alquran", MUSAWA 8.1. ejournal.uinsuka.ac.id/pusat/MUSAWA/article/ download/820/760 . 2016.

71 Mulia, Musda. Muslimah Reformis: Perempuan Pembaru Keagamaan. Cet. II; Jakarta: Mizan, 2005.

72 Mulyana, Deddy. Metodologi Penelitian Kualitatif, Paradigma Baru IImu Komunikasi dan IImu Sosial Lainya. Cet. VIII; Bandung: Rosda Karya, 2013.

73 Muslim, Abd Qadir. Kontribusi Perilaku Kepemimpinan Kepala Madrasah dan Motivasi berprestasi Guru terhadap Kinerja Mengajar Guru Berpendidikan S1 pada MTs Satu Atap Di kabupaten Sumenep Jawa Timur. Diss. Universitas Pendidikan Indonesia, 2013.http:// repository.upi.edu

74 Nawawi, Hadari. Kepemimpinan Mengefektifkan Organisasi. Cet. II; Yogyakarta: Gajah Mada University Press, 2003. 
75 Nazir, Moh. Metode Penelitian. Jakarta: Ghalia Indonesia, 2003.

76 No, Permendikbud. "Tahun 2013 tentang Kerangka Dasar dan Struktur Kurikulum Sekolah Menengah Atas." Madrasah Aliyah (69).

77 Northouse, Peter G. "Leadership: Theory and practice", Sage publications, Singapore, Printed in the USA. https://www.amazon.com/Leadership-Practice.../145220340. (2015), h. 15. Diakses 2 Februari 2017.

78 Northouse, Peter G. "Leadership: Theory and practice", Sage publications, Singapore, Printed in the USA(2015). (Diakses 2Februari 2017).

79 Notoatmodjo, Soekidjo. Metodologi penelitian kesehatan. Cet. I; Jakarta: Remaja Rosda Karya, 2010.

80 Novianti, Ida. "Dilema Kepemimpinan Perempuan Dalam Islam. Yin Yang 3.2 https: //yinyangstain.files.wordpress.com/ 07-ida-noviantidilema-kepemimpinan-perempuan. 2008.

81 Nuqul, Fathul Lubabin. "Hubungan Peran Jenis Dengan Minat Menjadi Pemimpin", repository.uinmalang.ac.id/Jurnal\%20Psikoislamika\%20\%28Peran\%20jenis\%20\%. 2006.

82 Pendidikan, Badan Standar Nasional, et al. "Standar nasional pendidikan." Diakses dari http://www. bsnpindonesia. org, pada tanggal 11 (2005).

83 Pendidikan, Peraturan Menteri, and Kebudayaan Nomor. "Tahun 2013 Tentang Kerangka Dasar dan Struktur Kurikulum Sekolah Menengah Atas/Madrasah Aliyah." (69). K Nomor - 69 - Jakarta: Depdikbud

84 Perempuan, Kementerian Pemberdayaan, Perlindungan Anak, and Badan Pusat Statistik. "Pembangunan Manusia Berbasis Gender 2013", Jakarta: Kementrian Pemberdayaan Perempuan dan Perlindungan Anak. https://www.kemenpppa.go.id/2013.

85 Ramadhini, Safitri dan Wiwin Hendriani. "Gambaran Trust Pada Wanita Dewasa Awal Yang Sedang Menjalani Long Distance Marriage", Jurnal Psikologi Klinis dan Kesehatan Mental 4.1 journal.unair.ac.id/download-fullpapers-jpkk869db9c43ffull.pdf. 2015.

86 Readety, Eve. "Peranan Kepala Madrasah dalam Manajemen Kurikulum dan Pembelajaran Madrasah Alam.(Studi Kasus SD Madrasah Alam Insan Mulia Surabaya)." Disertasi pasca sarjana UIN Jogjakarta (2008).

87 Ricklefs, Merle Calvin. "A History of Modern Indonesia since c. 1200", Palgrave Macmillan, https://he.palgrave.com/A-History-of-ModernIndonesia-s. 2008.

88 Ridwan Lubis, Muhammad and Ahmad Barizi. "Cetak Biru Peran Agama: Merajut Kerukunan, Kesetaraan Gender, Dan Demokratisasi 
Dalam Masyarakat Multikultural", Departemen Agama, Badan Litbang Agama dan Diklat Keagamaan, Puslitbang Kehidupan Beragama. https://balitbangdiklat.kemenag.go.id/.../498-Profil-Puslitbang-

Kehidupan-Keagamaa. 2005.

89 Robinson, Kathryn. "Ketegangan Antar Suku Bangsa Orang Bugis dan Masalah Penjelasan Antropologi Indonesia", Jurnal Budaya dan Masyarakat. www.jurnalalqalam.or.id/ index.php/ Alqalam/article/ viewFile/ 112/98. 2014.

90 Rohmaniyah, Inayah. "Gender Dan Konstruksi Perempuan Dalam Agama", Jurnal Ilmu Kesejahteraan Sosial 2.1. https: //journal.uny.ac.id/ index.php/ natapraja/ article/ download/ 11957/8553. 2013.

91 Ruslan, Murniati. "Pemberdayaan Perempuan Dalam Dimensi Pembangunan Berbasis Gender", http://download.portalgaruda.org/article.php?article $=251324$ \& val= 6754\& title $=$ Pemberdayaan Perempuan dalam Pembangunan Berbasis Partisipasi. 2010.

92 Sanjaya, Wina. Penelitian Pendidikan, Jenis, Metode dan Prosedur. Cet. III: Prenadamedia Group: Jakarta, 2015.

93 Sastriyani, Siti Hariti. "Studi Gender dalam Komik-komik Prancis Terjemahan", Humaniora https://jurnal.ugm.ac.id/jurnalhumaniora/article/view/812/654.16.2 .2004.

94 Sipayung, A. Sondang. "Pemimpin Perempuan di Lingkungan Pemerintahan : Studi Kasus Dalam Organisasi Pemerintahan Di Pemerintah Daerah Propinsi DKI Jakarta", Deskripsi Dokumen: http://lib.ui.ac.id/ opac/ themes/ libri2/ detail. jsp?id= 81869\&lokasi=lokal. 2012.

95 Situmorang, Nina Zulida. "Gaya Kepemimpinan Perempuan", Proceeding PESAT (Psikologi, Ekonomi, Sastra, Arsitektur dan Sipil) Vol (4 Oktober 2011), ISSN:1858-2559. Universitas Guna DarmaDepok https://www.neliti.com/id/conferences/pesat-2015.

96 Thoha, Miftah. "Perilaku organisasi konsep dasar dan aplikasinya." (Cet.II: PT. Raja Grafindo Persada, Jakarta, 2007).

97 Thoha, Miftah. "Perilaku Organisasi: Konsep Dasar dan Aplikasinya", Openlibrary. Telkomuniversity.Ac.ld. https ://openlibrary.telkomuniversity.ac.id/. Perilaku-organisasi-konsepdasar-da, 2012.

98 Thoha, Miftah. Perilaku Organisasi: Konsep Dasar dan Aplikasinya. Cet. I; Jakarta: Balai Pustaka, 2012.

99 Timple, A. Dale. Manajemen Mutu Terpadu Seri Manajemen Sumber Daya Manusia. Cet. V; Jakarta: Elex Media Komputindo, 2003.

100 Triyanto, Eko. Sri Anitah, and Nunuk Suryani. "Peran Kepemimpinan Kepala Sekolah dalam Pemanfaatan Media Pembelajaran Sebagai 
Upaya

Peningkatan

Kualitas

Proses

Pembelajaran", TeknologiPendidikan.www.academia.edu/19284916/Ma kalah landasan pendidikan 1.2. 2013.

101 Umar, Nasaruddin. Argumen Kesetaraan Jender. Cet. I; Jakarta: Paramadina, 1999.

102 Umar, Nasaruddin. Teologi Jender Antara Mitos dan Teks Kitab Suci. Cet. I; Jakarta: Pustaka Cicero, 2003.

103 Undang-Undang Sistem Pendidikan Nasional Nomor 20 tahun 2003, (Jakarta: Sinar Grafika Cet. 1, 2003).

104 UNDP Indonesia. "Partisipasi Perempuan dalam Politik dan Pemerintah", www.undp.or.id. Diterbitkan oleh UNDP Indonesia Hak Cipta (c) 2010.

105 Utsumi, Keiko, dkk. "Inequalities for Women in the California Divorce Law", Journal of Divorce \& Remarriage, Journal of Divorce \& Remarriage Publication details, including instructions for authors and subscription information. http://www.tandfonline.com/loi/wjdr20. 1992.

106 Wahjosumidjo. Kepemimpinan Kepala Sekolah, Tinjauan Teoritil dan Permasalahanya. Cet. IX; Jakarta: Raja Grafindo Persada, 2013.

107 Wang, Peiling. "Methodologies and methods for user behavioral research", Annual Review of Information Science and Tcehnology(ARIST), vol. 34, 1999.

108 Wardana, Dendik Surya. "Motivasi Berprestasi Dengan Kinerja Guru Yang Sudah Disertifikasi" Jurnal Ilmiah Psikologi Terapan 1.1. library.gunadarma.ac.id/journal/.../motivasi-berprestasi-dengan-kinerjaguru-yang-su 2013.

109

Wijaya, Aksin. "Menggugat Otentisitas Wahyu Tuhan: Kritik Atas Nalar Tafsir Gender", Safiria Insania Press, https://www.allbookstores.com/Menggugat-otentisitas-wahyu-Tuhankritik/97897997. 2004. 